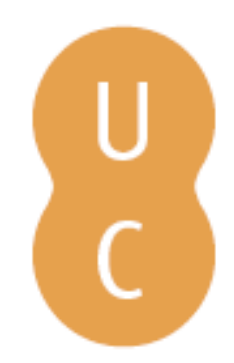

\title{
pompalina
}

\section{Sociedade e cultura na época Augustana}
Autor(es):
Oliveira, Francisco de
Publicado por: Centro de Estudos Clássicos e Humanísticos; Imprensa da Universidade de Coimbra

URL

persistente:

URI:http://hdl.handle.net/10316.2/31676

DOI:

DOI:http://dx.doi.org/10.14195/978-989-8281-47-0_1

Accessed : $\quad$ 26-Apr-2023 11:44:42

A navegação consulta e descarregamento dos títulos inseridos nas Bibliotecas Digitais UC Digitalis, UC Pombalina e UC Impactum, pressupõem a aceitação plena e sem reservas dos Termos e Condições de Uso destas Bibliotecas Digitais, disponíveis em https://digitalis.uc.pt/pt-pt/termos.

Conforme exposto nos referidos Termos e Condições de Uso, o descarregamento de títulos de acesso restrito requer uma licença válida de autorização devendo o utilizador aceder ao(s) documento(s) a partir de um endereço de IP da instituição detentora da supramencionada licença.

Ao utilizador é apenas permitido o descarregamento para uso pessoal, pelo que o emprego do(s) título(s) descarregado(s) para outro fim, designadamente comercial, carece de autorização do respetivo autor ou editor da obra.

Na medida em que todas as obras da UC Digitalis se encontram protegidas pelo Código do Direito de Autor e Direitos Conexos e demais legislação aplicável, toda a cópia, parcial ou total, deste documento, nos casos em que é legalmente admitida, deverá conter ou fazer-se acompanhar por este aviso.

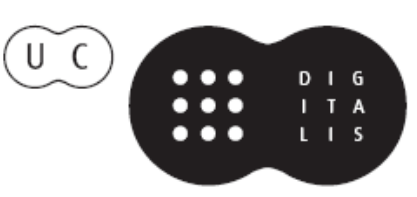




\section{Sociedade, Poder e Cultura no Tempo de Ovídio}

Maria Cristina de Sousa Pimentel e Nuno Simões Rodrigues (Coords.) 


\section{Sociedade e Cultura na época Augustana}

Francisco de Oliveira

Universidade de Coimbra

\section{Introdução ${ }^{1}$}

Mesmo quando juramos cautela, a compartimentação de épocas, tanto em literatura como em história, por vezes dificulta perceber que muito daquilo que consideramos próprio de uma época não é mais do que o ponto de chegada ou a síntese de tendências ou problemas que têm uma já longa elaboração.

Por isso, uma súmula sobre a sociedade augustana não pode ignorar desenvolvimentos sociais e políticos cujas raízes seguramente se encontram na longínqua época das Guerras Púnicas, trate-se da crise institucional e política, do alargamento da literacia em especial às mulheres, da evolução da moral sexual e das formas de relacionamento amoroso, visíveis tanto no teatro como nos elegíacos, dos problemas demográficos com os constrangimentos e tentativas para os resolver, da questão do regime e da sua legitimação, incluindo as formas de repressão e condicionamento da opinião, de que o célebre degredo de Ovídio seria um caso tão complexo quão exemplar.

Aliás, dois dos grandes lemas dessa época, o regresso ao passado e a ficção republicana ${ }^{2}$, justificam metodologicamente uma atenção a essas mesmas raízes.

\section{A crise institucional e cívica de fins da República}

A sociedade augustana é o resultado imediato da crise de finais da República, que se estendia da política à literatura, da filosofia ao quotidiano. $\mathrm{E}$ os romanos não ignoraram essa crise, tentaram encontrar respostas várias, em todos os campos onde ela se mostrava.

Lucrécio, apoiado na filosofia epicurista, propôs uma verdadeira ruptura. Mas o ideal quietista da escola, mesmo condenando a ambição política, a guerra ofensiva e o expansionismo ${ }^{3}$, não vai impedir a intervenção cívica, cinge-a à defesa da pátria quando esta é ameaçada, o que, em política externa, logo afronta o belicismo e o imperialismo romanos; na política interna, a ser verdade que a invocação de Vénus Genitriz na abertura do De rerum natura de Lucrécio é um eco de simpatia cesarista, por oposição à Vénus Victrix cultuada

${ }^{1}$ Trabalho desenvolvido no Centro de Estudos Clássicos e Humanísticos, no âmbito do Projecto Quadrienal da UI\&D-CECH/FCT POC 2010

${ }^{2}$ Bradley (1997) 364, sobre Pompeu: «he wanted his appointments to appear constitutional»; Tac. Ann.1.3.7, sobre Augusto: eadem magistratuum nomina; 1.81.3: quantoque maiore libertatis imagine tegebantur, tanto eruptura ad infensius seruitium; 4.19.4: Proprium id Tiberio fuit scelera nuper reperta priscis uerbis obtegere.

${ }^{3}$ Ver passos como Lucr. 2. 38 gloria regni, com reinterpretação racionalista do mito de Sísifo em 3. 995-1002; e, para o expansionismo, 1. 29-30 fera moenera militiai / per maria ac terras, 2. 13 rerumque potiri. 
pelos Pompeianos, e, apesar dos tratados epicuristas sobre a realeza, como o de Epicuro ou, mais provavelmente, o de Filodemo de Gádaros, o apregoado quietismo não impediu que um epicurista, Cássio, fosse um dos assassinos de Júlio César. Talvez pensasse que a pátria estava em perigo, o que legitimava tanto a intervenção política como o assassínio do tirano.

Também o poeta neotérico Catulo vai apresentar uma solução. Contra a severidade dos velhos que olham com desdém os novos costumes, contra os ideais de participação política tradicionais, representados por oradores como Cícero, contra as ligações políticas baseadas no conceito de amicitia, Catulo propõe um valor novo, o amor único e obsessivo, celebrado num pacto de amizade sensual. Com esta reformulação de conceitos, Catulo postula uma verdadeira revolução de valores e costumes, numa sociedade que não valorizava o amor-paixão como fundamento de uma ligação entre homem e mulher. Esta perspectiva vai ser continuada por elegíacos como Cornélio Galo, Tibulo e sobretudo Propércio, no contraponto da visão do amor em Lucrécio, Horácio e Ovídio ${ }^{4}$ Todavia, tanto nos neotéricos como em Horácio, por escolha estética, a mensagem seria destinada a um público intelectual restrito.

Outra proposta de solução da crise foi a apresentada por Cícero, numa perspectiva que posso considerar restauracionista. Esta expressão é metafórica, como se depreende do prólogo do livro V do Tratado da República, e na prática tem algumas confluências com as ideias de Salústio e de Tito Lívio sobre os inconvenientes das lutas entre facções, sobre a necessidade de regeneração moral e de uma concordia ordinum entre equites e aristocracia conservadora (boni). Na sua visão moralista, Cícero tem consciência muito aguda de que os tempos não iam a favor dos valores republicanos, subvertidos por tentativas de poder pessoal e abusivo, como no caso do poder tribunício, por decadência de costumes, e em especial pelo desinteresse dos melhores em relação à participação política. O proémio do livro I afronta exactamente as variadas controvérsias sobre a acção política como ciência-rainha e destino do sábio ou dos melhores cidadãos. $E$ já não é somente o quietismo político implícito no ideal epicurista de uoluptas, o prazer como critério de felicidade ${ }^{5}$. Cícero tem de confrontar-se também com os estóicos que identificavam virtude e saber, sábio e filósofo, mas que, na verdade, com a sua teoria dos indiferentes, reduziam a política a participação virtual e hipotética em casos extremos que dificilmente identificavam, respaldando-se num ideal contemplativo e intelectual que, na verdade, os levava a desdenhar o vulgo, isto é, a fugirem de se relacionar, na acção política, com não sábios.

Mas Cícero, além de afrontar esses posicionamentos filosóficos que apelavam à inacção ou a uma intervenção meramente virtual, tem de esconjurar também a experiência prática daqueles que, afinal, na política só tinham encontrado ingratidão, um registo verdadeiramente inglório, por vezes traduzido no tema do exílio, sentido como verdadeira chaga, que nem o cosmopolitismo cínico nem a teoria estóica dos indiferentes fariam sarar

\footnotetext{
${ }^{4}$ Oliveira (2009).

${ }^{5}$ Cf. Cic. Rep. 1.1 e 3.
} 
em almas tão arreigadas à urbe como a de Cícero $^{6}$ e a de Ovídio ${ }^{7}$, ou mesmo a do Melibeu de Virgílio (Ecl.1). Nesse aspecto, todos caminhavam na senda dos neotéricos, urbanos e requintados, consagrando a grande característica da civilização romana, a cultura urbana ${ }^{8}$.

Por esse motivo, no célebre Sonho de Cipião que encerra o livro VI e o Tratado da República, numa verdadeira temática em anel, Cícero vê-se obrigado a reformular o conceito de glória para atrair os sábios e os melhores cidadãos à política activa, e fá-lo prometendo-lhes a verdadeira imortalidade, aquela que colheriam quando, no momento estabelecido, a alma se libertasse do corpo e fosse recolhida entre os astros.

Esta aposta final torna-se universalmente convincente, pois tanto satisfaz os políticos sem preocupações filosóficas como todos aqueles cujas doutrinas inquiriam sobre a justificação da aç̧ão política, com um registo sincrético que abrange as tonalidades órfico-pitagórica, platónica e aristotélica, com reminiscências de todas as filosofias helenísticas, incluindo cinismo, e de teorias científicas várias", e que, afinal, quadrava muito bem com a mentalidade prática e não especulativa romana, onde retórica e diatribe funcionavam como cadinhos amalgamadores. De resto, mesmo sob o ponto de vista linguístico, epicurismo e evemerismo encontravam na heroizição ou divinização do bom governante uma imagem e uma concepção que lhes não repugnava ${ }^{10}$.

Mas a proposta de Cícero também se focaliza na figura do governante supremo, cuja panóplia de designações varia conforme a perspectiva, moral, económica, metafórica, mas que, no plano da teoria política, provavelmente se reduzia a duas hipóteses, princeps e rector. Por razões que não vou aqui explanar, penso que, no plano meramente teórico, o registo seria preferentemente rector $^{11}$; no plano prático, admito que a hipótese princeps, que segundo alguns teria servido de matriz à titulatura dos imperadores romanos, também quadraria com os precedentes existentes (princeps ciuitatis, princeps senatus) ${ }^{12}$.

${ }^{6}$ Tratado da República, em especial 1.5-6 e Pro domo sua.

${ }^{7}$ E.g. Tr. 4.10.113-114: não tem ouvintes; 5. 12. estiola o engenho; e Cartas do Ponto.

${ }^{8}$ Citroni (2006) 362 para os neotéricos; a diatribe cínica não considerava o exílio um mal (cf. Oltramare (1926) 47, tese 19); o exilado Musónio Rufo exemplificou no fr.9 que o sábio é feliz onde quer que esteja, porque todo o mundo é sua pátria, ideia nos antípodas de Ovídio, que parece utilizar clichés tradicionais na literatura do exílio (cf. Nascimento (2008) 16-17 e n. 40, onde também refere a teoria do exílio meramente poético, questão delineada em Навіneк (1998) 218-219 n. 9). A primazia da cultura urbana não impede por vezes uma saudade nostálgica do refúgio campestre (cf. Hor. S. 2.6 e em especial Tibulo, e.g. 2.3).

${ }^{9}$ Nesta questão, o eclectismo e o frouxo rigor científico justificam-se com o primado do objectivo ético: cf. Oliveira (2008) 280 n. 422; Nicolet (1988) 69-95, que acentua o carácter político da geografia entre os Romanos.

${ }^{10}$ Cf. Lucr. 5. 1-21: elogio de Epicuro.

${ }_{11}$ Ov. Tr. 2. 37-40: genitorque deum rectorque ... patriae rector ... paterque; Met. 15. 858-860; Plin. Nat. 2. 18, sobre Vespasiano; Tac. Ann. 3. 59. 6: a Druso, sucessor de Tibério, chamam rectorem generis humani.

${ }_{12}$ Tac. Ann. 1. 9. 7, sobre Augusto: Non regno tamen neque dictatura, sed principis nomine constitutam rem publicam; 3. 53. 4: por comparação com edis, pretores ou cônsules, Maius aliquid et excelsius a principe postulatur. Nos Anais, Tácito reserva o termo rector para algo como «preceptor» de um jovem príncipe (1. 24: Sejano, de Druso; 3.48: Sulpício Quirino, de Gaio 
Por outro lado, o regime que se adivinha, onde um único detentor concentra o poder supremo, uma monocracia que só partilha algumas tarefas com um coregente quando tem em vista preparar um sucessor, ou hipotéticos sucessores, necessita de estabelecer a sua própria legitimação e vai fazê-lo através da força das armas, da legalização de magistraturas extraordinárias (II Triunvirato), assumindo poderes especiais ou magistraturas que garantem ascendente ou capacidades essenciais (tribunicia potestas, cura annonae, praefectura morum, consulado), onde a eventual manutenção da designação republicana não esconde a alteração das características, em especial da anuidade e da colegialidade, antes disfarça a modificação do conteúdo e até o esvaziamento. Mas tudo isso tinha precedentes, desde Sila (ditador entre 82 e 80) a Pompeu (poderes extraordinários e sem base legal, cônsul único em 52) e Júlio César (praefectura morum em 46, tribunicia potestas em 45 e ditadura perpétua em 44$)^{13}$, sem que, durante um século, o Senado tivesse conseguido impor-se a todos os arrivistas e ambiciosos que se sucederam.

Nesse novo regime, a necessidade de legitimação leva a reforçar ou criar um sistema global de propaganda que utiliza todos os canais possíveis para reforçar a mensagem, da arquitectura à numismática, da literatura à religião, da arte ao espectáculo ${ }^{14}$, sem esquecer o culto imperial enquanto forma de lealdade entendida como exaltação de evergetas e benfeitores da humanidade, no sentido em que Lucrécio declarava Epicuro um deus e em que Cícero e Ovídio estabelecem um paralelo entre Júpiter e o governante máximo ${ }^{15}$.

Este sistema de propaganda, que de qualquer forma tem antecedentes, em especial em Júlio César ${ }^{16}$, vai assumir duas formas específicas: o histrionismo do poder e o mecenatismo literário.

Sobre o histrionismo do poder pretendo designar três realidades, e ambas implicam a consciência de que o poder tem necessidade de contacto directo com as grandes massas.

César); em 3.56.1-2 sobre a tribunicia potestas de Augusto, escreve: Id summi fastigii uocabulum Augustus repperit, ne regis aut dictatoris nomen adsumeret.

${ }^{13}$ Suet. Jul. 76 desenvolve o caso dos poderes extraordinários de Júlio César.

${ }^{14}$ Uma boa perspectiva geral sobre a arte como veículo da propaganda augustana pode encontrar-se em Zanker (1992), mas até nesse capítulo é muito útil o livro de GaLinsky (1996).

${ }^{15}$ Lucr. 5. 1-54; já o Salsicheiro de Aristófanes surge como numa teofania para salvar a pólis (Eq.146-149 soter ... phaneis); o próprio Augusto, que tão bem soube aproveitar o aparecimento do Sidus Iulium (cf. Verg. Ecl. 9. 47-49) em favor da divinização do seu pai adoptivo, em privado faria uma interpretação muito mais racionalista (Plin. Nat. 2. 93-94, Suet. Jul. 88 persuasione uulgi; cf. Oliveira (1992) 250-251, n. 417). Ver eventuais referências astrológicas e ideia de apoteose em Verg. Ecl. 4 e 5, Hor. Ep. 16.

${ }^{16}$ Já nomeado ditador por 10 anos, César deixa-se eleger cônsul em 46 e 45, e, novidade absoluta no mundo romano para um líder em vida, em 44 permite que a sua efígie apareça em moedas (cf. Galins KY (1996) 31). Octaviano foi mestre na utilização, como fez no aparecimento do sidus Iulium. A importância da religião para a organização do Estado foi bem entendida tanto por Júlio César, o reorganizador do calendário a quem Varrão dedica as Antiquitates, como por Augusto, que bem o testemunha nas Res Gestae, e.g. 19, 21 e 24; recorde-se a importância do seu sumo pontificado. 
A primeira faceta é a da promoção de jogos, com o próprio imperador a aparecer como editor ${ }^{17}$, substituindo nessa função edis e pretores. Augusto recorda nos seus Feitos essa realidade, que mesmo o imperador Tibério, pela generalidade das fontes considerado severo e pouco sociável e afável, não deixou de incentivar ${ }^{18}$.

A segunda implica a construção de recintos e locais adequados. $\mathrm{Na}$ óptica da vida quotidiana, a inauguração do primeiro teatro permanente, logo seguido de outros, como o de Marcelo e o de Balbo, forneceu espaços vocacionados para pontos de encontro galantes que são dos lugares preferidos por Ovídio para conquistas amorosas ${ }^{19}$. E é essa mesma realidade que permite a Ovídio responder à objecção dos que acusam a sua Ars por convidar ao vício, com uma conclusão surpreendente: então Augusto teria que arrasar os lugares de encontro, a começar pelos teatros (Tr. 2. 277: At uitia inuitat, v. 280: tolli tota theatra iube!; v. 313 ss.)! E, respondendo a outra acusação, se a Arte de Amar promove o deletério ou nimia lasciuia (2. 509 ss.), que dizer da política augustana, que consente jogos, inclusive com mimos a representar cenas de adultério, perante a passividade do imperador: scaenica vidisti lentus adulteria (v. 514)?!

A terceira refere-se tanto ao ambiente teatral e de simulação que regulava as relações na corte imperial, como ao facto de o imperador não desdenhar apresentar-se ele próprio como atleta, artista ou actor, sejam os casos de Calígula e de $\mathrm{Nero}^{20}$. No aspecto sociológico, esta realidade permitiu a Paul Veyne defender que os jogos contribuíam para a apolitização das massas ${ }^{21}$, parecendo esquecer que tais espectáculos suscitavam importantes movimentos de oposição ao poder ou, pelo menos, funcionaram como barómetro de popularidade, tanto no consulado de Júlio César em 59 a.C., como em 57 a.C., quando alusões ao exílio de Cícero se transformaram em manifestações a favor do seu regresso, contra a vontade de Clódio ${ }^{22}$, em 57 e 55 a.C. com manifestações relacionadas com Pompeu ${ }^{23}$, como no final da ditadura de Júlio

${ }^{17}$ Cf. Res Gestae, 20.1 (restauro do Teatro de Pompeu), 21. 1 (Teatro de Marcelo), 22-23 (jogos vários, incluindo naumaquias).

${ }^{18}$ Plin, Nat. 35.28 minime comis imperator; 34. 62: Tibério pressionado no teatro pelo povo; Tac. Ann. 4. 2. 4: Tibério recebe o epíteto facilis, relacionado com teatro (cf. 3. 72, onde a comitas é atribuída a Germânico); em 1.54 apresenta alguma condescendência perante dissensões entre actores, mas só o fazia por fingimento, para não romper uma tradição de tolerância herdada de Augusto, e mesmo neste caso por atenção aos gostos de Mecenas; 1. 76, Tibério não assiste a jogos de gladiadores presididos por Druso, fosse por desprazer por multidões, fosse para não suscitar manifestações do público ou dos actores e suas claques, como as relatadas no $§$ seguinte; Suet. Tib. 34 (regulamenta mas não proíbe).

${ }^{19}$ Ov. Ars 1.89-100; Rem. 751-756 (non indulgere theatris).

${ }^{20}$ Para Calígula, ver Suet. Cal. 32.5 (treina-se com um mirmilão), 54 (suas exibições em espectáculos vários); para Nero, abone-se com Suet. Nero 10. 5, 11, 20-25, 49 (célebre exclamação Qualis artifex pereo!).

${ }^{21}$ VEYNE (1976).

${ }^{22}$ Cic. Sest. 115-132, um verdadeiro manual de agitação e propaganda.

${ }^{23}$ Segundo Cic. Att. 2. 19. 3, no ano de 59 a.C., apesar de manipular contiones e comitia, César, mal acolhido no teatro, reage com desagrado, escrevendo a Pompeu, também ele visado; 
César (Suet. Jul. 80. 4), no reinado de Augusto, quando os manifestantes gritaram contra as leis sobre o casamento (Suet. A. 34. 3), ou no de Tibério, obrigado por constantes reclamações do povo no teatro a restituir uma estatueta que o imperador desviara para uso privado, exactamente o Apoxiómeno de Lisipo (Plin. Nat. 34. 62).

Quanto ao mecenatismo, fenómeno extremamente estudado e nem por isso menos controverso, trata-se de um movimento de protecção aos intelectuais que se afirma quando se pretende reenquadrar ou retomar a «tradição da literatura dirigida à comunidade política», cuja ligação fora subvertida pelos neotéricos, poetas no geral ricos e podendo descartar protectores ${ }^{24}$. Torna-se evidente que os mecenas procuravam fomentar nos seus protegidos manifestações consentâneas com os seus gostos e ideais; mas também é certo que isso não impediu recusas ou concretizou-se em meros apontamentos ocasionais $\mathrm{s}^{25}$, e que, em última instância, o protegido tinha a faculdade de mudar de protector. É o caso de Virgílio e de Horácio, que transitam do círculo de Polião para o de Mecenas, tendo Asínio Polião e Messala uma sensibilidade menos empenhada em relação ao novo regime ${ }^{26}$.

No caso de escritores sem desafogo económico, a questão tem a ver com a inexistência de quadro legal que permitisse a um escritor receber direitos de autor, tornando-o dependente do apreço e boa vontade dos grandes ${ }^{27}$.

Mas não se pode entender mecenatismo, e refiro-me directamente ao caso de Mecenas, como puro policiamento e condicionamento da arte, pois que, ao aceitar determinado mecenas, qualquer artista ou literato romano sabia que ia estabelecer relações de clientela, desde os mais remotos tempos republicanos reguladas por deveres e direitos mútuos, em especial a troca de serviços e apoios $^{28}$. Assim, ao integrar determinado círculo, o artista automaticamente fazia a sua oposição ideológica, uma opção consequentemente não imposta, mas consentida e consciente. $\mathrm{O}$ caso é tanto mais interessante quanto Virgílio, o cantor dos valores nacionais e da nova ordem nas Geórgicas - com

cf. Lucano, 7. 9-12: na noite anterior à batalha de Farsalo, Pompeu sonha com os aplausos recebidos no teatro; sobre as manifestações e sua eficácia, ver Oliveira (1993).

${ }^{24}$ Citação de Cit roni (2006) 256-257. Sobre o estatuto social dos neotéricos, cf. Griffin (1985) 116. A nível institucional, o precedente está na protecção do Estado romano a Lívio Andronico e à corporação dos escribas; a nível privado, na colocação da estátua de Énio no túmulo dos Cipiões e no próprio Círculo dos Cipiões; ver entourage de letrados de grandes personagens como Sila e Quinto Lutácio Cátulo.

${ }^{25}$ Hor. Epod. 14; Carm. 1.6 e 12, 4.15 e S.2.1. 10-20; genericamente, a opção neotérica pela poesia menor implica a recusa dos géneros maiores; Propércio, e.g. 2. 1, 10, 36; 3. 1, 3; 4. 1, irá nobilitar a poesia erótica, em consonância com a valorização que faz do amor como opção vivencial. Tal não o impediu de ocasionalmente cantar Augusto e um tema tão significativo como a batalha de Áccio; cf. CaIrns (1984) 129-168.

${ }_{26}$ Prop. 3. 9. 47: Te duce uel Iouis arma canam caeloque minantem ... (recusatio da épica e exemplo de Mecenas); cf. Gil (1985) 133.

${ }_{27}$ Habinek (1998) 106, recorda tanto o pouco dinheiro pela venda dos livros como as queixas de Juvenal em relação às benesses recebidas dos protectores.

${ }^{28}$ Para a inclusão do mecenatismo nas relações de clientela, ver Saller (1982) 7-39 e, em geral, Galinsky (1996) 225-287 e 245 («The poets had their own minds»). 
homenagens a Octávio e a Mecenas estrategicamente colocadas ao longo da obra, desde a abertura ao fecho - , o cantor da gesta romana e da gens Iulia na Eneida, fora amigo de Asínio Polião e de Cornélio Galo29; e Horácio, o poeta do Carmen Saeculare $e^{30}$ expõe tanto a ideologia augustana (protecção de Febo Apolo, aproximação de Augusto à divindade, optimismo da nova idade do ouro, virtudes do bom governante) como especificamente a ideologia do principado (imagem do governante como medicus, com os registos linguísticos inerentes, como fessus, salutaris); e em composições como o Epodo 9, as Odes Cívicas e em especial as Odes Romanas ${ }^{31}$, esse mesmo Horácio lutara em Filipos em 42 a.C. do lado republicano ${ }^{32}$.

Por outro lado, o mecenatismo terá correspondido essencialmente a uma primeira fase do período augustano, aquela em que a memória das guerras civis era ainda muito viva e experienciada pelos intelectuais em causa - em especial Virgílio e Horácio. Num segundo momento, depois da consolidação desse processo e já sem a memória directa dessa fase conturbada e traumática, e particularmente após algum afastamento e a morte de Mecenas ${ }^{33}$, o próprio regime poderá ter enveredado por uma atitude de censura e até de rigor em relação aos intelectuais que gravitavam em torno de Valério Messala Corvino, como o elegíaco Ovídio em $8 \mathrm{dC}$, o historiador Tito Labieno em $12 \mathrm{dC}$, o orador Cássio Severo entre 8 e $12 \mathrm{dC}^{34}$. Consolidado o regime, talvez os próprios literatos sentissem menos necessidade de o celebrarem ou entendessem que era tempo de dar voz a outras realidades sociais, o que justificaria atitudes como as de Horácio, o qual «só se tornou poeta lírico depois de Áccio» ${ }^{35}$.

O próprio Ovídio, sendo de família equestre e por isso economicamente independente ${ }^{36}$, mesmo na sua temática amorosa condena o amor-paixão e, de

${ }^{29}$ Recorde-se a hipótese de as Geórgicas terminarem com um elogio de Cornélio Galo, depois da sua queda política substituído pelo episódio de Aristeu e Orfeu; cf. Griffin (1985) 180-182.

30 Conforme observei durante a discussão das comunicações apresentadas, o Carmen Saeculare (veja-se a sua transcrição no presente volume, no capítulo da autoria de P. B. Falcão). Cf. Galinsky (1996) 100-106.

${ }^{31}$ Hor. Carm.3.1-6 (em especial sobre a primeira, ver Woodman (1984) 83-94); cf. 4.5 e 15.

${ }^{32}$ Hor. Carm.2.7. Veja-se Du Quesnay (1984) 57: «... after Philippi, Horace changed sides. He joined Maecenas and that means that he committed himself to support of the Triumvirs and of Octavian».

${ }^{33}$ Refiro-me aos anos 23/22 e 8 a.C.; cf. Tac. Ann. 3. 30; Suet. A. 66. 6.

${ }^{34}$ Ver Cizec (2008) 140-142, para quem Cremúcio Cordo foi vítima do ódio de Sejano; Citroni (2006) 642-643. Em relação a Cássio Severo (ver infra n.114), diz Tac. Ann. 1. 72 que, por iniciativa de Augusto, ele foi a primeira vítima de uma interpretação abusiva da antiga lex maiestatis, condenado ao exílio, provavelmente em 8 d.C., por ter escrito libelos difamatórios contra particulares; quanto a Labieno, cujos escritos não seriam libelos, mas teriam dignidade literária, vendo os seus livros queimados, encerrou-se no túmulo, onde se deixou finar. Ver GiL (1985) 139-140.

${ }_{35}$ Citação de Citroni (2006) 522; cf. 439-440.

${ }^{36}$ Para a independência de autores de origem equestre ou aristocática, como o mimógrafo Labério, Varrão, Ático e os poetas neotéricos, cf. Citroni (2006) 356-357. Parece que devemos enquadrar aqui figuras independentes como Messala, Asínio Polião, Salústio e Tito Lívio. 
acordo com a moral tradicional, apresenta exemplos de harmonia conjugal ${ }^{37}$. Neste aspecto, o relato da partida de Ovídio para o desterro, com a consequente despedida da esposa, na elegia $T r$. 1. 3, é uma soberba proclamação de um exemplo do amor conjugal romano, o do próprio Ovídio e de Fábia, na qual se entrecruza a realidade romana com os motivos da amante elegíaca, das heroínas épicas e trágicas, numa linha de continuidade que liga a Aretusa de Propércio às protagonistas das Heroides, em especial Laodamia ${ }^{38}$.

Para além de supor a ideia de um governante único para o corpo do império (cf. Tr. 2. 230-231), Ovídio também apresenta consonâncias frequentes com os lemas da política augustana ${ }^{39}$, particularmente na primeira versão dos Fastos, anterior ao exílio e dedicada a César Augusto, conforme confessa o próprio autor (cf. Tr. 2.549-553), onde a afirmação da religião como instrumentum regni contraria a mensagem lucreciana e se aproxima do movimento restauracionista religioso de Augusto ${ }^{40}$, cuja divinização é referida no final de Fastos $^{41}$ e cantada no fecho das Metamorfoses (15. 745-870), onde, sob a tutela de Vénus e em ligação com a lenda troiana (cf. Fast. 4. 120-124), o sidus Iulium assinala a divinização de Júlio César e a futura apoteose de Augusto, sem que se possa em qualquer desses momentos encontrar sinal de insinceridade ${ }^{42}$.

Note-se ainda que até no registo linguístico e conceptual Ovídio compreendeu a essência do regime augustano: assim, em Fast.1. 282, o tema do encerramento das portas do Templo de Jano (Caesareoque diu numine clausus ero); em Fast. 1. 617-636, a exaltação e justificação do cognome de Augustus, partilhado com Júpiter ${ }^{43}$; em Fast. 1. 709-724, o tema da paz simbolizado

${ }^{37}$ Catul. 61 e 68.73-76 Protesilau e Laodamia; Cic. Att.1.18. 1 e Fam. 14. 1; Tib. 2. 2; Prop. 1.15 e 2.9 (exemplos mitológicos), 3.12 e 4. 3. 49: Omnis amor magnus, sed aperto in coniuge maior; Ov. Am. 3.13; Ars, 3.1.15ss.; Tr. 3.3 à esposa, optima coniunx; Met. 8, e.g 631ss. (exemplo de Filémon e Báucis); Tac. Ann.1.33: Agripina caracterizada por castitate et mariti amore, 1. 41. 3: por praeclara pudicitia; 3.33-34: discurso de Valério Messalino e de Druso contra a proposta de impedir os governadores de província de levarem as esposas no séquito. Para exemplos de amor conjugal e adultério em Ovídio, ver Frécaut (1972) 232 e, no geral, Griffin (1985) 112 ss., em esp. 141 n. 95.

${ }^{38}$ Prop. 4. 3; Ov. Ep. 13 (Laodamia e Protesilau), Tr. 4.3 (Fábia como esposa fiel e amante elegíaca), 5. 14. 28 e 36 e Pont. 3. 1.73 e 105 ss.: socialis amor; cf. FEDELi (2008) esp. 109-110 n. 78.

${ }^{39}$ Ov. Tr. 2. 61-64 afirma que os seus livros estão cheios de elogios de Augusto, tanto os que foram objecto de reprovação passada como os que se anunciam para as Metamorfoses ( $T r$. 2. 555-562), que receberam inspiração do mesmo Augusto, a quem dedicara os Fastos (Tr. 2. 547-552; em 14 dC, em nova edição, a dedicatória passa para Germânico). Independentemente da discussão sobre a natureza da adulatio ou até sobre alguma ironia, certo é que o mesmo Ovídio dirá que Augusto estaria pronto a perdoar (Pont.4.6.13-16), como escreve Luisi (2008) 37 («Lo stesso Ovidio ebbe sentore del perdono di Augusto»), relacionando com a hipotética reaproximação de Augusto a Agripa Póstumo nos anos 7 e $8 \mathrm{dC}$, promovida por Q. Fábio Máximo (cf. Plin. Nat.7.150, Tac. Ann.1. 5, D. C. 56.30).

${ }^{40}$ Fast. 3. 415-428 sobre a importância do título de pontífice ou titulis pontificalis honor.

${ }^{41}$ Fast. 4. 954, que associa Febo, Vesta e Augusto: aeternos tres habet una deos.

${ }^{42}$ McKeown (1984) 187, referindo-se aos Fastos, fala em «inability to accomodate such passages to the general spirit of the poem»; Galins KY (1996) 228: «It makes no sense to call him anti-Augustan or un-Augustan; in a way, he is the truest product of the Augustus age».

${ }^{43}$ Fast. 608: bic socium summo cum Iove nomen habet. 
pelo Altar da Paz ou Ara Pacis; em Fast. 5.545 ss., a referência ao Templo de Marte Vingador e à recuperação dos estandartes perdidos por Crasso frente aos Partos; em Fast. 2. 119-142, a analogia entre Júpiter e Augusto, explorada a favor deste, com ênfase no título de pater patriae e de princeps, por oposição a dominus ${ }^{44}$. Gera-se mesmo a ideia de um vicariato de Júpiter ${ }^{45}$ semelhante ao preceituado em Cícero para o governante ideal ${ }^{46}$.

Em suma, como escreve J.-P. Martin, «Ovide a réalisé là le travail de compréhension le plus précis qui ait jamais été fait de la pensée et des désirs d'Auguste» ${ }^{47}$.

De resto, os amores galantes e sem compromisso afectivo que Ovídio apresenta em Amores, Arte de Amar e Remédios de Amor ${ }^{48}$, têm por objecto uma amica, meretrix ou puella cuja característica básica é a infidelidade ou a partilha do seu amor, características da meretrix já retratadas no teatro plautino. Desse modo, dificilmente podiam ser ofensivos da moral $^{49}$, tradicionalmente tolerante

${ }^{44}$ Cf. Cic. Rep. 1. 64; Ov. Tr. 2.39 e 181.

${ }^{45} \mathrm{Em}$ Tr. 2. 54-55 refere-se-lhe como deus e vir maxime, onde deus é, portanto, elogio exagerado, a exemplo de Verg. Ecl. 1. 6-8 (deus) vs 1.42 (illum ... iuvenem), como observa Ramage (1987) 100 n. 243. Para a apoteose de Augusto, cf. Hor. Ep. 1. 17. 33-35 (alusão) e, para o vicariato de Júpiter, Carm. 1. 12; Plin. Nat. 27.3 em relação ao império romano. Para uma leitura crítica ou até paródica dos motivos augustanos em Ovídio, vejam-se, no presente volume, os contributos de P. F. Alberto, em relação a Tr.3.1 (só na superfície poderiam as referências condizer com a ideologia augustana; opinião contrária tem FEDELI (2008), e.g. 8788, a propósito de Tr. 1. 3), de D. Lucas sobre as Metamorfoses; cf. McKeown (1984) 169-187 sobre os Fastos.

${ }^{46}$ Cic. Rep. 1.50 e 56, em conjugação com a missão de governar a terra imposta por deus ao homem, tal como é exposta no Sonho de Cipião, e.g. 6.13 (cf. Oliveira (2008a) 254 n. 115; Hor. Carm. 1.12 e 3.5; Ov. Tr. 2. 33-40 e Fast.2.131-132.

${ }^{47}$ Martin (2006-2008) 88.

${ }^{48}$ FrÉCAUT (1972) 230: «Ovide annonce dès l'abord son dessein qui est d'étudier uniquement la technique des liaisons galantes, d'en dégager des règles qui serviront à l'édification des libertins; sans doute, il délimite clairement son champ d'observation d'où il veut bannir tout ce qui se rapporte au mariage, à la famille, à l'adultère». Posso interpretar como consciência de ausência de ilícito ou contrário à ideologia augustana o passo de Ov.Ars 1.33: Nos Venerem tutam concessaque furta canemus, que o próprio cita em $\operatorname{Tr} .2 .249$, em resposta aos seus detractores, que pelos vistos eram antigos (Ov., Rem. 361-398). Opinião contrária tem Boyd (1997) 16: «Ovid uses the normally conservative role of didactic poet to challenge and subvert the moralizing legislation characteristics of Augustus' reign ... cause of eventual exile». Ora a condenação da poesia erótica em Rem. 757-766 é justamente feita no quadro da cura do amor-paixão, que em Verg. Ecl.10 aparece sem remédio. Ver infra n. 81.

${ }^{49}$ Especificamente em relação à Ars, o próprio Ovídio abona com uma citação que nela não existe nada contrário à leis (Tr. 2.239 ss.: nullum legisses crimen in Arte mea ... non tamen idcirco legum contraria iussis ... Nil nisi legitimum concessaque furta canemus (cf. Pont. 3. 3. 69); v. 305-306: Et procul a scripta solis meretricibus Arte / summovet ingenuas pagina prima manus. O problema era essencialmente ideológico: a leuitas e o otium neotéricos - e Ovídio insiste no carácter de devaneio e jogo, com frequência irónico, da sua poesia erótica - o seu epitáfio quadraria com a epígrafe Tenerovm Lvsor Amorvm, de acordo com Tr. 3. 3. 73-75, cf. 4.10.1 -, contradiziam a grauitas, a seueritas e o onus ou pondus tradicionais (Ov. Tr.2.213 ss.); todavia, mesmo na elegia por vezes ocorrem tonalidades épicas (cf. Tib. 1.7, a Messala) e os elegíacos ocasionalmente avançam para estilos mais elevados, como na narrativa das Metamorfoses, concebida como uma alternativa à Eneida, no dizer de Galins ky (1996) 262. 
com esses amores desde que não estivesse em causa o património familiar, a reputação ou o cumprimento dos deveres cívicos ${ }^{50}$. E não me parece fácil contestar que, sob o ponto de vista da temática amorosa, Ovídio não diz nada que já não tivesse sido dito por neotéricos e elegíacos, herdeiros da poesia alexandrina e da Antologia Palatina, e de forma muito mais ofensiva para a ideologia augustana ${ }^{51}$, ou mesmo que não estivesse já delineado na comédia nova, na comédia latina ${ }^{52}$, na sátira de Lucílio, em Lucrécio e Horácio ${ }^{53}$.

$\mathrm{E}$ até mais do que nos precedentes literários, o tema dos amores galantes fazia parte da vida quotidiana, que convivia com profusa iconografia de exemplos de amores ligeiros reminiscentes da mitologia, do drama, da épica, da pintura e da escultura ${ }^{54}$.

\section{Alargamento da cultura. Literacia feminina}

Uma das grandes características do final da República e início do Principado é uma verdadeira explosão da divulgação da cultura e da literacia, que, sendo comprovada inclusive com a descoberta de bibliotecas em campos militares, do Eufrates à Britânia ${ }^{55}$, se estende de modo especial ao público feminino e fornece uma explicação sociológica para o facto de a mulher se ter tornado fonte de inspiração na elegia amorosa ${ }^{56}$.

No caso da cultura feminina, os precedentes explícitos não são muitos, mas existem, com registos em Lucílio, em Terêncio, no epitáfio de Cornélia mãe dos Gracos, do séc. II a.C. («aprazível a sua fala») 57.

Sendo certo que a poesia neotérica supõe um círculo literário restrito onde a mulher era elemento activo, todavia, a obra de Ovídio é, nesse aspecto, a

${ }^{50}$ Cf. Ov. Fast. 4. 133-164, sobre Vénus Verticordia; Cic. Cael. 28, 42-43, 48 ss.

51 Ov. Tr. 370: Denique composui teneros non solus amores. Neste ponto, concordo com Навіnек (1998) 155-156: a auto-defesa de Ovídio oferece a Augusto uma oportunidade para alterar o castigo.

${ }^{52} \mathrm{O}$ próprio Ovídio o recorda em Tr.2.369: Fabula iucundi nulla est sine amore Menandri, / et solet his pueris virginibusque legi «Não há comédia do popular Menandro despojada de temática amorosa, / e ele é correntemente lido por rapazes e donzelas». A relação entre comédia, e mesmo tragédia, e elegia está bem documentada em Griffin (1985) 203-210, e cito p. 207: «These ressemblances between Comedy and Elegy are more than verbal echoes. They relate to central ideas and attitudes of the genre».

${ }^{53}$ Ver Oliveira (2009).

${ }^{54}$ Cf.P1.,As. 174-175: figura da meretriz em escultura e pintura; Ter., Eu. 583-589: contemplação de pintura de Júpiter e Dánae prepara o estupro (cf. Prop. 2. 32.59-60 e Griffin (1985) 139: «a woman taking money»); carme 64 de Catulo (bodas de Peleu e Tétis, com écfrase de pintura do mito de Teseu e Ariadne a ilustrar os perigos do adultério; Prop.2.6.27 ss., sobre pintura erótica de paredes; Ov. Met. 10. 242-297: estátua feita por Pigmalião («womanufacture», como escreve WYKE (2002) 161-163); Tr. 2. 420, 521-528, 523-524: pintura erótica exposta em público e em privado; cf. Plin. Nat.35.17-18, 70 e 72; 36.22 e, para as artes decorativas, 14.140: uasa adulteriis caelata e 33.04: Auxere et artem uitiorum inritamenta; in poculis libidines caelare iunit ac per obscenitates bibere.

${ }_{55}^{5}$ Habinek (1998) 118. A inscrição de Vipasca é também elucidativa.

${ }^{56}$ Cf. Prop. 2. 1. 4: é a amada que dá inspiração; Griffin (1985) 54-55.

${ }^{57}$ Sobre a cultura feminina, em especial da matrona de classe elevada, ver Hemelrijk (1999). 
mais clara afirmação da importância dos novos públicos, não pela inexistência de precedentes isolados de voz feminina ${ }^{58}$, mas por um conjunto de factores explícitos que claramente lhe permitem definir um público-alvo feminino e generalizado: a dedicatória do livro III da Arte de Amar, o facto de o destinatário implícito de Remédios de Amor ser também feminino; o surgimento de uma literatura com voz e pontos de vista femininos nas Heroides ${ }^{59}$. E é extremamente sintomático que Ovídio tenha consciência desta realidade sociológica irreversível quando se defende dos detractores que, embora concedendo que o público de Ovídio não são as matronas, o acusam de permitir que estas aprendam as malas artes dos amores lascivos junto daquelas a quem o livro é destinado. Contrapõe ele que isso seria supor que uma matrona ficaria impedida de ler o que quer que fosse (v. 265: crimen liber omnis habebit), pois nos mais insuspeitos autores, como Énio, irá encontrar histórias de devassidão ${ }^{60}$.

Sendo este o exemplo sociologicamente mais relevante dos novos públicos, não é de menos importância a feitura das obras em função de um público de não especialistas, o que supõe uma vertente de divulgação que encontramos em Cícero, com a escolha do diálogo como forma de cativar público vasto em obras como Tusculanae, De senectute, De amicitia; no Horácio das Sátiras; em Varrão, no De uita populi Romani e nas Sátiras Menipeias; em Tito Lívio; em Higino; em Germânico e em Plínio o Antigo ${ }^{61}$. Tal alargamento torna possível a decisão de Ovídio de não dedicar a sua obra a um destinatário individualizado, mas ao público em geral, indeterminado e vasto.

${ }^{58}$ Sobre o círculo catuliano, cf. Citroni (2006) 347. Recordem-se a poesia neotérica das filhas de Hortênsio e de Cornifício (Citroni (2006) 356); a Semprónia de Sal. Cat. 25 (posse uersus facere); a saphica puella de Catul. 35; o epitáfio de Cornélia em Prop. 4. 11; a carta de Aretusa a Licotas em 4.3; a poesia de Sulpícia (Tib. 3. 8-18). Em relação à maioria destas vozes femininas, poesia de autoria masculina, НАвıneк (1998) 122 ss., e.g. 130, usa a expressão «ventriloquism» para se referir à inexistência de expressão oral feminina e de falta de visibilidade social própria (casos das Heroides de Ovídio e da Élia Gala de Prop. 3. 12); uma perspectiva feminista encontra-se em WYкE (2002), esp. 155-191.

${ }^{59}$ Prop. 2. 13. 11-12: «Que o meu prazer seja recitar versos no regaço de uma jovem culta, / $\mathrm{E}$ ver os meus poemas aprovados pelos seus ouvidos sinceros»; 2.24. 22; 3.3. 19: turba puellarum si mea uerba colit?; cf. Ov. Tr. 2. 435-436 (referência a Perila, um caso bem destacado; Habinek (1998) 134-136, na p. 124 observa que, no geral, «learned women are not in turn authors»; cf. 9. 209-210 para exemplos contrários).

${ }^{60}$ Ov. Tr. 2. 253-264; em Pont. 3. 3. 49-69: Amor atesta que não ensinou adultérios a matronas; cf. Tib. 3. 1. 7-8, atribuído a Lígdamo: Carmine formosae, pretio capiuntur auarae: I gaudeat, ut digna est, versibus illa meis. Todavia, o argumento é essencialmente formal; cf. HEMELRIJ (1999): «the type of the docta puella poetry adored in love poetry may have inspired some upper-class women to follow their example in certain respects». A meu ver, está aqui implícito o receio de confusão entre matrona e meretrix; cf. WYKE (2002) 35 para a conexão entre amante elegíaca e mulher augustana e 113-114, sobre a Cíntia e a Aretusa de Propércio; e Oliveira (2009).

${ }^{61}$ A procura de destinatários que não são «os mais doutos» liga sintomaticamente Lucílio a Cícero e Plínio o Antigo; ver Cic. Rep. 1 . fr.1c = Plin. Nat. praef. 7 : praeterea est quaedam publica etiam eruditorum reiectio. Vtitur illa et $M$. Tullius...: nec doctissimis. Manium Persium haec legere nolo, Iunium Congium uolo. Quod si hoc Lucilius. 
NofinaldaRepública,ointeressepelaculturaalarga-se extraordinariamente e abrange campos que vão da pintura à geografia e etnografia e se espelham em excursos astronómicos, geográficos e etnográficos de autores tão diversos como Cícero, Salústio, César, Ovídio, Séneca ${ }^{62}$ ou Tácito, e em domínios tão variados como os exempla retóricos, os mirabilia, a mitologia, a botânica, a astrologia e a zoologia, assumindo uma vertente unificadora no enciclopedismo de Varrão e de Plínio o Antigo.

$\mathrm{O}$ incremento da cultura era de tal modo forte que Roma se sente guindada à condição de centro cultural, ideia a que Cícero dá voz no Discurso em Defesa do Poeta Árquias, ao atribuir a Roma a capacidade de exercer um ingenii iudicium, isto é, decidir, premiar e consagrar a qualidade artística, destinando à imortalidade o poeta que, ao celebrar Roma, também a destinara à perenidade ${ }^{63}$. É esta a essência do discurso, que sintomática e coerentemente desvaloriza o caso jurídico em apreço.

É também revelador que a própria anomia de algumas ordens sociais, incluindo a dos equites, que se virá a transformar numa elite funcional fortemente empenhada na produção intelectual e na promoção da cultura, gerará um desenvolvimento cultural de extrema amplitude, que vai da exposição pública e privada de obras de arte, mapas arquitectónicos, leituras públicas com respectivos auditórios, bibliotecas públicas, como a projectada por César e Varrão e depois aberta por Asínio Polião no templo de Apolo no Palatino, em 28 a.C., a suceder às bibliotecas privadas ou semi-públicas anteriormente existentes, como a de Luculo, cenário dos livros III e IV do De finibus de Cícero, até à movimentação editorial implícita tanto nos paedagogia de Ático como nas sucessivas reedições de Ovídio. Recordem-se ainda os livros ilustrados, as esferas e planisférios para estudar astronomia, as técnicas de restauração, o surgimento de museus e parques zoológicos ${ }^{64}$.

Tão grande fermentação intelectual, que transforma a cultura em moda, com o inerente snobismo e exagero de alguns (cf. Cic. Fin. 1. 10), implicava porventura uma cultura livresca que por vezes seria mais superficial do que profunda, fornecida por cartilhas, colectâneas, pintura, prontuários de leitura rápida, catálogos de exempla retóricos tipificados e repetitivos. Seria este tipo de cultura, de que recordamos os Erotika Pathemata do poeta helenístico Parténio, que em parte tornava possível uma literatura como as Metamorfoses e Fastos de Ovídio, os Facta ac dicta memorabilia de Valério Máximo, dedicados a Tibério, e a sobredose de referências mitológicas nos elegíacos em geral, com excepção

${ }^{62}$ Para citar um único exemplo, veja-se o catálogo das cidades gregas em Sen., Tro. 814-861, onde a curiosidade geográfica das troianas quase esconde as suas dores de cativas.

${ }^{63}$ A expressão ingenii iudicium é-me sugerida por Plin. Nat. praef. 6 e 7.108.

${ }^{64}$ Depois da primeira em 39 a.C., a abertura de bibliotecas públicas teve seguimento imediato com as instaladas por Augusto no Templo de Apolo em 28 a.C. e no pórtico de Octávia em 23 a.C.; sobre a presença de temática amorosa em todos os géneros e autores, cf. Ov. Tr. 419-420,: Suntque ea doctorum monumentis mixta uirorum, / muneribus ducum publica facta patent «E esses temas, misturados com as obras de doutos varões, / foram postos à disposição do público graças à munificência dos chefes». НАBineK (1998) 103-121 procura demonstrar que a aristocracia curou de enquadrar tal movimento de modo a continuar a sua hegemonia. 
de Tibulo, que haveria de provocar uma completa expurgação posterior de todo o aparato mitológico em Lucano.

Por outro lado, o interesse do grande público pela cultura tornava a própria cultura ainda mais apetecível como arma de condicionamento da opinião, através da propaganda e do mecenatismo cultural. Horácio revela consciência desse movimento, no qual todavia vê necessidade de acautelar a escolha criteriosa dos veículos da mensagem ${ }^{65}$.

\section{Demografia}

No plano demográfico, o final da República e inícios do Principado é também um momento de crise, tanto na questão da natalidade como na taxa de mortalidade. O problema demográfico torna-se de importância acrescida por razões de recrutamento de tropas, sendo por isso mais agudo em momentos de guerras prolongadas e em especial durante as proscrições e guerras civis, mas também por necessidade de recrutamento de pessoal administrativo para gerir um império cada vez mais largo e em vias de centralização burocrática, e não apenas política.

Para resolver o problema da base de recrutamento militar, os Romanos, que não tinham a tradição de utilizar tropas mercenárias, encontraram várias soluções: a imposição de obrigações militares nos tratados celebrados aquando da deditio ou da integração no Estado Romano; o alargamento da base de recrutamento com a remuneração do serviço militar; a extensão da duração do serviço; e, sobretudo, o recrutamento de tropas auxiliares, que eram as primeiras a entrar em combate ${ }^{66}$, com os legionários a só serem lançados na batalha em situações mais difíceis ${ }^{67}$ - prática que os inimigos dos romanos viam como sinal de fraqueza ${ }^{68}$.

Uma consequência lateral desta situação concretizou-se na devoção dos militares ao seu chefe, aquele que lhes garantia o pagamento do soldo e, sobretudo, de um montante significativo no termo do serviço, que significava de facto o pecúlio da reforma ${ }^{69}$. Não podemos esquecer que a noção de segurança social ou estado providencial não existia e que a satisfação das expectativas das tropas era uma condição de segurança que, à falta de pagamento em espécie, era satisfeita com a distribuição de terras, muitas delas confiscadas ou expropriadas. Foi o que sucedeu na Campânia, em 59, para os veteranos

${ }^{65}$ Hor. Ep. 2. 1, 2. 2. 1-140, 2.3 (Carta aos Pisões); cf. Навіneк (1998) 88-102.

${ }^{66}$ Cf. Tac. Ann. 3. 45, Sílio avança contra Sacrovir ... cum legionibus duabus incedens praemissa auxiliari manu.

${ }^{67}$ Tac. Ag. $18,32,35-36$.

${ }^{68}$ Ver Tac. Ann. 3. 40.5 (discurso de Sacrovir): nibil ualidum in exercitibus nisi quod externum. Para os problemas militares em geral, remeto para o contributo de J. Varandas, neste volume.

${ }^{69}$ Os Commentarii de Sila e de Júlio César, ao fixarem nomes de simples soldados, deixam perceber essa realidade; Sal. Cat. 11. 5-6 culpa Sila pela perversão do exército para assegurar a sua lealdade (cf. Jug. 96); Tac. Ann. 1. 17. 6-9 testemunha a rebelião de tropas por causa do soldo; cf. Suet. Jul. 25. 5 (César duplicou o soldo), A. 49 (importância da questão: ad certam stipendiorum praemiorumque formulam adstrinxit), Nero 32. 1 (ut stipendia quoque militum et commoda ueteranorum portrahi ac differri necesse esset). 
de Pompeu, e depois da batalha de Filipos em 42, com desapossamentos que deixaram eco nos Rerum rusticarum libri de Varrão, atingiram a propriedade do poeta Virgílio (cf. Ecl. 1 e 9) e acaso também a de Horácio, e são referidas por Suet.Jul. 38. Foi o que também sucedeu quando Augusto desmobilizou 32 legiões após a batalha de Áccio ${ }^{70}$.

Mas se para o recrutamento militar se encontravam várias soluções, já o fomento da natalidade de cidadãos e a sua preparação ou educação para tarefas de cidadania e de exercício de funções administrativas e dirigentes se revelava mais difícil. A situação já se colocara durante a II Guerra Púnica, por 131 a.C., certamente perante um quadro demográfico negativo relacionado com as inúmeras guerras e a necessidade de governar mais territórios, tendo $\mathrm{Q}$. Cecílio Metelo Macedónico pronunciado um discurso em defesa da natalidade (de prole augenda), conhecido através de Aulo Gélio e com eco em Lucílio, fr. 678-9 M. Tal situação agravara-se posteriormente, a partir da época dos Gracos, com a violência política, as proscrições de Sila e posteriormente dos triúnviros, a Guerra Social, as revoltas do escravos e, finalmente, as Guerras Civis, a afirmação de Augusto e do seu regime, circunstâncias que provocaram dizimações por toda a Itália e em escala inaudita, com as proscrições do II Triunvirato a liquidarem, só por si, 300 senadores, entre eles Cícero, e 2000 equites. Mesmo quando essas guerras fratricidas, plus quam ciuilia, se passavam fora de Itália ${ }^{71}$, como Dirráquio, Farsalo, Filipos e Útica, os seus agentes eram cidadãos romanos e as chefias das camadas dirigentes.

A situação era agravada por dificuldades e obstáculos insuspeitos à procriação: pesadas restrições, inclusive de ordem económica, como a limitação da fortuna à propriedade fundiária, recaíam sobre os senadores; novas regras de higiene, como os banhos quentes, provocavam infertilidade masculina, e a água canalizada fazia grassar o saturnismo; hábitos alimentares prejudiciais, como as cenae recheadas de iguarias exóticas, causavam graves problemas de saúde ${ }^{72}$; filosofias que apregoavam a misantropia, como o cinismo, ou que consentiam o casamento mas sem entusiasmo, como o epicurismo, ou que, no caso de alguns estóicos, celebravam ideais teóricos e contemplativos, constituíam obstáculos pouco consentâneos com apego à família ou preocupações com a procriação.

É também de admitir que a mesma consequência resultasse da nova ênfase no amor-paixão, que está presente em Virgílio, tanto na figura trágica de Dido na Eneida como nas Bucólicas e até com tonalidades homo-eróticas, como nas Ecl. 2.8 e 10 ou em Catulo e Tibulo, inclusive na arte de amar pederástica

${ }^{70}$ Ver Hor. S. 2. 6.55 ss.; Res Gestae 3 (instalação de 300.000 veteranos em colónias, que terão sido 28), 15.3, 16 e 17 (BRADLEY (1997) 463). A devoção ao chefe era uma consequência tanto da reforma militar mariana, com recrutamento de capite censi e respectivo pagamento, como dos precedentes de recrutamento privado de legiões para intervenção em favor do Estado, sejam os casos de Pompeu durante a Guerra Social (Plin. Nat.7.95-98) e de Júlio César nas campanhas da Gália (Suet. Jul. 24.2).

${ }^{71}$ Evoco a expressão bella plus quam ciuilia de Luc.1.1.

${ }^{72}$ Cf. Catul. 44.1-9; Hor. S. 2.2. 70 ss.; Plin. Nat.9.104, sobre a moda de peixes e mariscos: ex tota rerum natura damnosissimum uentri mare est tot modis; 14.137 ss.; 26. 43: eoque mores uenere, ut homo maxime cibo pereat. 
da elegia 1.4. Esse novo ideal viria a ser transposto para o interior da relação matrimonial e nesta buscaria os modelos de conjugalidade e fidelidade inerentes aos códigos do amor elegíaco, em especial com Propércio, o qual «procurou recuperar, na nova ética do amor livre, certos valores específicos do casamento e investi-los daquele calor passional que, no matrimónio, era normalmente desvirtuado» ${ }^{73}$. Ora, para além de retardar o casamento, tal ênfase levaria à preferência por uniões em que a procriação era uma impossibilidade ou um inconveniente, sobretudo para a mulher, ou que, mesmo dando filhos, não produziam cidadãos ${ }^{74}$.

Aduzo uma última razão para a dizimação da camada dirigente e o desaparecimento de famílias da aristocracia e da nobreza: a anomia decorrente, por um lado, dos novos papéis, mais activos, igualitários e masculinizados da mulher, que poderia provocar no masculino algum desconforto ${ }^{75}$, e, por outro, a dificuldade de adaptação a um novo tipo de relacionamento com a comunidade cívica e com o regime, o que, mesmo descontando a clementia de César e em parte de Augusto, levou a oposições e, sobretudo, à banalização do suicídio, muitas vezes aceite em alternativa à execução, outras vezes adoptado como protesto, e em consequência exercido num ambiente encenado (cf. Tac. $A g .42$ ambitiosa morte); de qualquer forma, os processos movidos por delatores de classes elevadas contra os seus pares, que têm precedentes na época dos Gracos, anunciam uma verdadeira autofagia no ambiente da corte ou no Senado, que julgava as causas onde os senadores estavam implicados ${ }^{76}$.

A relegatio de Ovídio pode ser exactamente relacionável com esta anomia, se o crimen praticado tem a ver com conhecimento ou implicação nalguma

${ }^{73}$ Veja-se Tib. 3. 3. 31-32: Haec alii cupiant; liceat mibi paupere cultu / securo cara coniuge posse frui (atribuído a Lígdamo); cf. Citroni (2006) 567. Por outro lado, o modelo elegíaco vai colorir a relação conjugal, como quando Ovídio transforma a uxor amans Fábia em heroína elegíaca (cf. Tr.1.3; FEDELI (2008) 90-94 e 111).

${ }^{74}$ Cf. Ov. Am. 2.13 e 14. Para uma abordagem do problema do aborto e contracepção, ver Oliveira (2008b), em esp. p.73, 77 e 81-82 e notas correspondentes; e, neste volume, o capítulo de C. S. Pinheiro.

75 Para o importante papel social e político desempenhado pelas mulheres dos exilados e para a imagem da mulher masculinizada e castradora em Ovídio, ver no presente volume, respectivamente, o contributo de J. N. Torrão - E. M. Oliveira (também Fedeli (2008) 103104 observa que o argumento da utilitas justifica que Fábia não se suicide para poder prestar auxílio a Ovídio exilado) e os de C. André e de C. M. Mora. O igualitarismo sexual, por vezes sob a forma de primazia, iniciativa e violência da mulher, é um pressuposto em Lucrécio e na imagem da Lésbia de Catulo, e.g. 8, 107 e 109; Tib. 1. 6. 67-72, 2.1.75-78, 2. 3. 79 (imperium dominae; cf. Cic. Cael. 67, imperatrix para definir Clódia) e 2. 4; Prop. 2. 20. 27: Cum te tam multi peterent, tu me una petisti; diria mesmo que é a condição do seruitium amoris elegíaco e dos motivos do exclusus amator e do paralausithyron, «serenata diante de uma porta fechada». Ver Griffin (1985) 54-55 (capacidade de a mulher dizer não ao amante); 206-207 (a sujeição do amante à mulher tem origem na comédia plautina).

${ }^{76}$ Tac. Ann. 3. 66. 1: Paulatim debinc ab indecoris ad infesta transgrediebantur; Citroni (2006) 239-240: delatores lançam ataques contra a aristocracia senatorial na época dos Gracos. A Lex Paedia de interfectoribus Caesaris de 43 a.C. punia com interdição de água e fogo e confiscação de bens dos cesaricidas, recompensando os delatores (crime tipificado como parricidium publicum); Rotondi (1966) 435; Suerbaum (1971) 61-99, esp. 69 n. 21. 
conjura $^{77}$, ou mesmo se, como me parece mais provável, as opiniões de Ovídio se inclinaram para o elogio de uma linha política antoniana, hostil a Tibério e favorável a Germânico, ou foram consideradas conuicium «vitupério» contra a pessoa do príncipe e portanto sancionadas com base na lex maiestatis existente desde tempos republicanos ${ }^{78}$.

Como procurou Augusto resolver estes problemas demográficos? Antes de mais, repita-se que o que preocupava Augusto era a carestia de cidadãos, e, antes de mais, de cidadãos da elite, conforme decorre do clausulado da legislação que promulgou em 18/17 a.C. (lex Iulia de adulteriis coercendis e lex Iulia de maritandis ordinibus), e que veio a reformular em 9 d.C. com a lex Papia Poppaea, com o objectivo de regular a moral sexual e incrementar a natalidade. Mas torna-se difícil imaginar Augusto ofendido por uma Arte de Amar publicada por Ovídio entre 1 a.C. e 1 d.C., pior ainda reagindo uns 7 anos depois da sua publicação e um quarto de século distante da primeira legislação moral $^{79}$.

Este raciocínio parece-me igualmente válido mesmo no caso de se admitir que o poeta finge quando insistentemente apregoa que o seu amor galante não é o amor procriativo e regulado pelo casamento, mas o amor multívago de Lucílio, de Lucrécio e de Horácio. E cabe recordar, a este propósito, que a ocorrência de termos como matrona, uir, uxor não se refere necessariamente a uma relação matrimonial, menos ainda quando Propércio, antecedido por Catulo, transfere a linguagem e os conceitos matrimoniais para o âmbito do amor-paixão $0^{80}$.

Além disso, também como Lucrécio e Horácio, e de certo modo como Propércio, 1. 4, Ovídio vai oferecer, em Remédios de Amor, os meios para a cura do amor-paixão e medicar aqueles que, contra o objectivo explicitado no prólogo da sua Ars, 1.1-34, se tinham desviado de um amor guiado pela razão. Este papel de mestre e de médico do amor é rastreado na recorrência dos termos ars, como em arte regendus Amor, ou doctus, magister, praeceptor, peritus, e em metáforas várias ${ }^{81}$. Poderíamos mesmo acrescentar que o amor

${ }^{77} \mathrm{O}$ error, distinto de scelus, referido em Trist. 2. 109 e 208, 4. 10. 90.

${ }^{78}$ A suposição de um erro político real e enquadrável no crime de lesa-majestade (ver, entre outros passos, Tr. 1. 5. 84: laesi ira dei, 2. 108: laeso numine, 3. 6. 23: laesi Caesaris ira, 4. 10. 98: laesi principis ira) parece-me defendida com bastante lógica por Luisi (2008) esp. p. 23-25 (sobre o triângulo amoroso entre Helena, Menelau e Páris) e 31-45; no presente volume, relacionam-se com esta problemática as comunicações de N. S. Rodrigues e de R. Furtado, cujo levantamenteo prosopográfico desvaloriza a tradicional oposição entre Júlios e Cláudios.

${ }_{79}$ Ov. Tr. 2. 543-544: Ergo quae iuueni mibi non nocitura putaui / scripta parum prudens, nunc nocuere seni «Assim, escritos que julguei não me iriam prejudicar sendo um jovem pouco prudente, me prejudicam agora que sou velho»; cf. GiL (1985) 140-141; GalinskY (1996) 268-269.

${ }_{80}$ Cf. Galinsky (1996) 272 ss. Ver Tib. 1. 6. 15: fallacis coniunx incaute puellae; Prop. 2. 6. 42: semper amica mibi, semper et uxor eris «serás sempre a minha amada, e sempre também a minha esposa»; o amor é fides e foedus duradouros em Prop. 2. 20. 34: ultima talis erit quae mea prima fides; o uso do termo para uniões entre escravos é atestada em inscrições e já é causa de controvérsia em P1., Cas. e.g. 69: Seruin uxorem ducent aut poscent sibi? «Uns escravos vão casar-se ou vão pedir alguém em casamento?» (trad. de A. Couto: Plauto, Cásina, Lisboa, 2006).

${ }^{81}$ Este raciocínio arreda a hipótese de os Remedia serem uma palinódia ou retractatio 
meretrício, tal como em numerosas comédias plautinas e terencianas, poderia implicitamente funcionar como uma espécie de iniciação erótica e sentimental pré-matrimonial dos adolescentes romanos ${ }^{82}$.

Também nesta questão demográfica o imperador soube recorrer ao passado, mas introduzindo algumas nuances e até inovações. É mesmo impressionante a arte com que Augusto inovou sem poder ser acusado de não ter precedente republicano. De facto, o novo poder vai perfilhar inicialmente a clemência de César para justificar o perdão concedido a muitos pompeianos e estava mesmo disposto a poupar Catão de Útica se este não se tivesse suicidado, assim preservando famílias à custa da expectativa de futura não oposição ao regime; nalguns casos, o imperador vai refazer a fortuna de membros da elite para garantir o censo necessário à manutenção do status senatorial ${ }^{83}$; promover elites municipais e provinciais, num movimento iniciado por Júlio César ${ }^{84}$ e apoiado por Salústio; estabelecer programas de enquadramento da juventude através do lusus Troiae e, posteriormente, da iuuentus neroniana e da criação de alimenta; e dar isenções fiscais e visibilidade social aos progenitores de famílias numerosas.

Que a preocupação de Augusto era essencialmente com a classe dirigente, ressalta com clareza da já referida legislação sobre moralidade e natalidade: por um lado, os privilégios concedidos são directamente proporcionais ao status social, e, quando não são contestados ${ }^{85}$, tornamse apetecidos simplesmente porque davam visibilidade social, como no caso do ius trium liberorum, ou implicavam vantagens políticas ao descerem a idade mínima de acesso a magistraturas ${ }^{86}$; por outro, as leis sobre manumissão procuram evitar libertações em massa, em especial as testamentárias, dificultando o acesso de ex-escravos à cidadania. É o caso da Lex Fufia Caninia de manumissionibus, de 2 a.C., e da Lex Aelia Sentia de manumissionibus, de 4 d.C. ${ }^{87}$

(FrÉcaut (1972) 235). Referindo-se às suas obras eróticas, o próprio Ovídio proclama que a maior parte é mendax e ficta (Tr. 2.355). Ver supra n. 48.

82 Oliveira (2006) 333-355, onde se recorda Ter. Eu. 930-940 (amor meretrício é uma prevenção para o futuro) e $A d$.149-152 (rito de passagem).

${ }^{83}$ Ver Suet. A. 40; Tac. Ann. 2. 37, sobre Marco Hórtalo ... inlectus a diuo Augusto liberalitate decies sestertii ducere uxorem, suscipere liberos, ne clarissima familia extingueretur, 2. 48: Tibério por um lado ajuda financeiramente, por outro deixa sair livremente do Senado os que haviam perdido a qualificação do censo necessário. Esta auto-exclusão parece uma das facetas da anomia da classe senatorial.

${ }^{84}$ A promoção de elites provinciais é representada na Hispânia pelos Bocchi de Salacia e pelos Balbi de Gades; e, de origem turdetana, pelos Senecae de Corduba, os Trabii de Italica. No presente volume, o capítulo de A. Guerra dá conta das transformações sociais e políticas na Lusitânia no tempo de Augusto. Quanto à política de Júlio César, cf. Suet. Jul.76. 5 e 80. 3-4.

${ }^{85}$ Cf. Prop. 2. 7: alegra-se com a abolição de uma lei que obrigaria os celibatários a casar e que, por isso, o liberta de dar filhos e soldados à pátria; tratar-se-ia de um projecto de 28 a.C., que enfrentou oposição; cf. Hor. Carm. 3. 24; Tac. Ann. 3. 28, Suet. A. 34. 1-4 (lei contornada); Griffin (1985) 23-24; Galinsky (1996) 128 ss.

${ }^{86}$ É o caso implícito em Tac. Ag. 6; Plin. Ep. 10.94 pede tal distinção para Suetónio Paulino, que não tem filhos.

${ }^{87}$ Sobre a legislação referida e seu conteúdo, ver Rotondi (1966); Galinsky (1996) 128-140. 
Um outro aspecto curioso é que, tendo por objectivo moralizar uma sociedade que caíra na lassidão de costumes, sendo limitativa da liberdade individual e defensora de ideais tradicionais, como a estabilidade e a fidelidade conjugal consagradas nos ideais da uniuira e do homem de um só matrimónio ${ }^{88}$, afinal de contas essa mesma legislação dificulta a oposição do progenitor ao casamento; estabelece prazos curtos para que viúvos e viúvas tornem obrigatoriamente a casar, assim contrariando a imagem de fidelidade ao defunto marido prometida pela Dido virgiliana, sem a poder louvar pelos amores com Eneias ${ }^{89}$; impede um senador e seu descendente até ao $3^{\circ}$ grau de desposar uma liberta; afrouxa a tutela sobre a mulher e, no fim de contas, mitiga as sanções sobre o divórcio; legislação posterior virá mesmo a desvalorizar o casamento por confarreatio $0^{90}$.

Nesta medida, a legislação augustana, na sua pouca eficácia demográfica, mais não fazia do que reconhecer a realidade também constante da literatura, a progressiva emancipação feminina ${ }^{91}$, a desenvoltura de costumes e $o$ desaparecimento das formas de casamento mais tradicionais, como o casamento in manum e a sua forma mais solene e elitista, a confarreatio.

Tal desenvoltura aparece referida em autores insuspeitos, como Horácio, Carm.3.5, onde o elogio da idade de ouro trazida por Augusto, com a sua regeneração de costumes, vem a par de uma preterição de realidades que se pretendem esconder - lassidão de costumes, adultérios, incestos, maridos complacentes, de tal modo que o fecho parece um grito interior que adivinha um futuro bem pior («uma progénie ainda mais viciosa») - , como que antecipando os comportamentos relatados por Juvenal (1.55-57) ou por Tácito: mulheres casadas, e até da ordem equestre, a reivindicarem o direito de se prostituírem, e maridos a consentirem (Tac. Ann. 2. 85); mulheres voluntariosas e imperialistas, que, no séquito dos generais, até dão ordens às tropas ou que, se deixadas em casa, logo se dariam ao adultério (Ann. 3 . 33-34).

Ora a verdade é que, na sua própria vida privada, a domus Caesaris dava exemplo claro tanto de lassidão de costumes como da importância política das

${ }^{88}$ Em Tac. Ann. 2. 73. 3, Germânico é elogiado uno matrimonio, certis liberis; o termo certus ocorre em Ov. Med. 45 (Certus amor morum est), ideia que tem continuidade nos v. 49-50.

${ }^{89}$ A coloração elegíaca de Dido refere-se naturalmente ao livro IV da Eneida; cf. Wy KE (2002) 97-98.

${ }_{90}$ Refiro-me a uma lex de flaminica diali hipoteticamente de 24 d.C. Tac. Ann. 4.16 dá a explicação sociológica para a decadência do casamento por confarreatio, adivinhando-se a resistência das mulheres a tal estatuto, que juridicamente as inferiorizava.

${ }^{91}$ A emancipação feminina tanto está ligada a normativos jurídicos (a viuvez e o divórcio transformavam a mulher em sui iuris, ajudando a explicar mulheres emancipadas como a Lésbia de Catulo (provavelmente a Clódia que Cícero denigre no Pro Caelio com laivos de exclusa amica), como ao poderio económico feminino (Cic. Rep. 3. 17: controvérsia sobre as heranças femininas), já visível na comédia nova e na comédia plautina e terenciana, com a figura da uxor dotata. No final da República e início do Principado, a popularidade crescente do mimo atesta seguramente a temática da mulher, com actrizes, costumes soltos, homossexualidade, adultérios e maridos traídos (cf. Ov. Tr.2.497 ss.), pendente libidinoso do ardente serviço amoroso feminino cantado por Sulpícia (Tib. 3.11-13). 
mulheres da familia Caesaris, agentes efectivos de poder e da sua legitimação, a par com o exército, o Prefeito do Pretório e os libertos imperiais ${ }^{22}$.

Terá a relegatio de Ovídio sido causada por essa nova realidade ${ }^{93}$ ? Pelo menos parece deduzir-se que os acontecimentos muito recentes (Tr. 2. 97-99: si non extrema nocerent ... ultima me perdunt) são bastante posteriores à data da publicação da Ars e haviam sido causados por um golpe da fortuna (Tr. 2.85 e 107), por um casus (v. 108), por uma única tempestade ${ }^{94}$, o que é claramente incompatível com a publicação de livros que, tratando-se de Ars ou Amores, haviam tido várias datas de saída a público e já teriam sido objecto de nota censória ou de exclusão de bibliotecas ${ }^{95}$. Ovídio queixa-se, em consequência, de ter o destino que não tiveram Tibulo - e quem não pensará na arte de amar homo-erótica da elegia 1.4.7-72, ou nas elegias 1.2 e 6.9? -, nem Propércio (Tr. 2. 463-466), nem Virgílio (Tr. 2.533-538).

Mas, até pela incompatibilidade com necessidades de curto prazo, as restrições legais ou a censura moral não conseguem resolver o déficit demográfico, menos ainda problemas tão importantes como o da sucessão imperial, vendo-se o imperador na necessidade de recorrer a mecanismos já existentes na tradição romana, como a adopção, a manumissão, a promoção de famílias equestres, de veteranos, de domésticos e sobretudo de libertos, e até de provinciais, como já visionara Júlio César.

Horácio, enquanto filho de um liberto, é um exemplo claro de alguém que, de ascendência itálica ou servil, chegou ao convívio com a nata da aristocracia, mas que, quando Augusto quis ir buscá-lo ao Círculo de Mecenas, viu serlhe oferecida uma função sem dúvida elevada, mas também marcada pela ligação a uma classe social inferior - situação tanto mais irónica quanto o próprio Horácio procura ignorar esse seu estigma pessoal (Hor. S. 1. 6. 89 ss.). O mesmo problema de aceitação plena terá Sejano: quando pede a Tibério para casar com Livila, a filha do falecido Germânico e então viúva de Druso, depara com uma recusa cortês mas bem justificada ${ }^{96}$, certamente fundada numa realidade a que nem o próprio imperador conseguia evitar - o inconformismo

${ }^{92}$ Ver Tac. Ann. 2. 43. 6-7: a corte está dividida entre dois possíveis herdeiros de Tibério (Germânico e Druso): ... aemulatione muliebri ... Diuisa namque et discors aula erat tacitis in Drusum aut Germanicum studiis; 2. 72: antes de morrer, Germânico recomenda a Agripina ... neu regressa in urbem aemulatione potentiae ualidiores inritaret, 3. 64: relações conflituosas entre Tibério e sua mãe Júlia Augusta; 4. 39-40: influência de Sejano; quanto à impudicitia reinante, cf. 3. 24. No campo de literatura, o contributo de C. Teixeira neste volume ilustra a importância política feminina através da imagem de Dido em Virgílio e Ovídio.

${ }^{93}$ Ov. Tr. 2. 137: relegatus, non exul; cf. 5. 11. 21; Pont. 4. 15. 2: relegatus Naso.

${ }^{94}$ Tr. 2.100: una procella; 109: illa namque die; 121-122: sub uno / sed non exiguo crimine; 210: semel.

${ }_{95} \operatorname{Tr} .2 .7-8 ; 211-212$ : ... turpi carmine factus / arguor obsceni doctor adulterii; 3. 1. 6568 e 5.12.67-68: exclusão das bibliotecas.

${ }_{96}$ Tac. Ann. 4. 39-40; cf. 3. 36: desdém por libertos e escravos; Tac. Ann. 3. 75: mobilidade social: Ateio Capitão chega ao Senado graças a Augusto, mas era descendente de centurião, gerando odium ex inuidia; Suet. $A$. 63. 3: Augusto procurou casar Júlia mesmo na ordem equestre; já Salústio propugna o alargamento e a regeneração moral da classe dirigente defendendo uma aristocracia da uirtus, cf. Citroni (2006) 422-423. 
social existente, exemplificado pela influência e pela promoção de libertos, em particular os libertos imperiais ${ }^{97}$.

\section{Delito de opinião (lex maiestatis)}

A propósito da época de Augusto e início do Império, e tendo em vista tanto a relegatio de Ovídio como os julgamentos por lesa-majestade no tempo de Tibério, muito se tem discutido sobre a existência de delito de opinião nessa época. Cita-se amiúde o julgamento de Cremúcio Cordo como um apelo à liberdade de expressão $0^{98}$. Ora, Cremúcio Cordo publicara ainda no tempo de Augusto e não fora então perseguido por ter elogiado Bruto e exaltado Cássio, elogio que estava longe de ser inusitado, para não dizer que era recorrente e se enquadrava bem na ficção republicana do regime. Por isso, Cordo defende-se dizendo que a lex maiestatis só o poderia visar se ele tivesse atacado o príncipe ou a sua progenitora, e por actos, não por escritos ${ }^{99}$.

Efectivamente, na análise de factos como o delito de opinião e as acusações com base na lex maiestatis, não podemos esquecer que a condenação à morte por injúrias contra alguém em sua vida já estava prevista na Lei das Doze Tábuas e que essa medida é louvada por Cícero (Rep. 4. 12). O contexto parece ter na mira a uituperatio em ambiente de representação cénica, onde seria especificamente proibido o ataque a altos magistrados como os Cipiões ou Catão, entendimento que já está implícito nas tentativas de limitação do onomasti komodein na Atenas clássica, pois a confusão entre dirigentes e Estado é fácil de fazer ${ }^{100}$.

De qualquer forma, o legalismo romano, e em especial no Principado, não permitiria condenações sob a lex maiestatis sem fundamento, pelo menos sem cumprir formalidades e tipificar o crime, cuja legalidade poderia advir somente da existência de precedente ${ }^{101}$.

Tácito acusa Tibério de ter, por instigação do cônsul Pompeu Macro, restaurado a ancestral lex maiestatis, mas dando-lhe um conteúdo diferente

${ }^{97}$ Plin. Nat.33.32-36 sobre os equites e o direito ao anel de ferro e sua perversão por libertos; 33. $134-135$ e 35.201.

98 Sobre toda esta problemática, remeto para Suerbaum (1971) 61-99, muito bem fundamentado, e para Haffter (1971) 104-110. O texto clássico base é Tac. Ann. 4. 34. 1: Cremutius Cordus postulatur nouo ac tunc primum audito crimine, quod editis annalibus laudatoque M. Bruto C. Cassium Romanorum ultimum dixisset; cf. 3.76 (efígies de Cássio e Bruto consentidas por Tibério nos funerais de Júnia) e 16.7 (Nero tem entendimento contrário). Cf. Cizec (2008) 146-151.

${ }^{99}$ Veja-se Cizec (2008) 208, n.146-151.

${ }^{100}$ Cic. Rep. 4. 11. Cf. Suerbaum (1971) 81-82 e em esp. n. 60, a propósito da invocação das práticas gregas por Cremúcio Cordo em Tac. Ann. 4.35.1 (por conveniência de argumentação, Cordo silencia as tentativas de limitação do onomasti komodein). GiL (1985) 114 ss., relaciona a severidade da pena com eventual ligação a práticas mágicas.

${ }^{101}$ Tac. Ann. 4. 69. 1: na época da primazia de Sejano, os delatores de Tício Sabino têm consciência de que seria improcedente qualquer acusação sem número adequado de testemunhas (Consultant quos memoraui quonam modo ea plurium auditu acciperentur). Mas Tácito insiste nas inovações penais feitas por Tibério (Ann. 2.27, sobre Libão Druso: tum primum reperta sunt; 2. 30. 5: noui iuris repertor Tiberius; 4. 34. 1, sobre C. Cordo: nouo ac tunc primum audito crimine). 
do antigo, a exemplo de Augusto, que fizera condenar Cássio Severo por vituperar varões e mulheres ilustres com seus libelos difamadores e escritos provocadores (de famosis libellis specie legis eius tractauit ... qua uiros feminasque inlustris procacibus scriptis diffamauerat) ${ }^{102}$. É que também Tibério se sentia ofendido com versos anónimos que atacavam a sua crueldade, a sua soberba e as discordâncias com sua mãe (carmina incertis auctoribus uulgata in saeuitiam superbiamque eius et discordem cum matre animum) $)^{103}$.

Para Tácito, estas parecem ser inovações, pois a prática anterior, de ascendência republicana, visaria somente traição militar, sedição popular ou má gestão. Parece tratar-se de pura parcialidade de Tácito, pois as leis republicanas sobre maiestas, como a lex Cornelia de iniuriis, de 81 a.C., já sancionavam libelli famosi, tal como eram punidas as ofensas a magistrados e particulares pela lex Cornelia de maiestate, do mesmo ano, que se aplicaria tanto ao domínio privado como ao público, usa o termo declamari e estabelece a pena de interdição de água e fogo, também prevista na lex Iulia de maiestate, de 46 a.C.

Estes e outros dados permitem a L. Gil afirmar que «el estado republicano contaba desde muy antiguo con las bases legales suficientes para una enérgica represión de estos excesos que el principado no tuvo más que repristinar para cortarlos de raíz» e considerar que a lex Cornelia de iniuriis constituía o instrumento legal para justiçar libelos difamatórios ${ }^{104}$. E, para além da história do encarceramento de Névio por ordem ofensa aos Metelos, existe ainda notícia de que Pompeu fizera condenar à morte Valério Sorano por ter revelado em escrito o nome secreto de Roma, o que obviamente se enquadra no conteúdo mais tradicional do conceito de crime de maiestas ${ }^{105}$. Entre outros exemplos referidos por Cremúcio Cordo, César e Octaviano teriam perdoado os ataques políticos de Catulo e de Fúrio Bibáculo, parecendo implícita uma distinção entre literatura e puro denegrimento vexatório e panfletário, do qual a historiografia partidária adversa se poderia aproximar ${ }^{106}$.

Assim, nem Augusto, com a lex Iulia maiestatis de 8 a.C., que dá continuidade à referida lei cesariana de 46 a.C. e visa ofensas à pessoa ou nome do imperador, sancionando com exílio e confiscação de bens qualquer ataque e reservando a pena capital para crimes de perduellio, nem Tibério no ano 15 d.C., criaram, portanto, algo de novo. De resto, é o próprio Tácito a recordar que no julgamento de Apuleia Varila, Tibério não quis que fossem sancionados impropérios contra si ou sua mãe (Ann.2.50: probrosis sermonibus). Podendo este facto ser entendido como uma decisão pessoal de não utilizar todas as possibilidades e interpretações legais, também fica claro que a grande

${ }^{102}$ Tac. Ann.1.72, como a citação seguinte.

${ }^{103}$ Sobre as formas e a terminologia da maledicência e da invectiva (carmen, dictum, epigramma, factum, famosus, flagitium, flagitare, incantare, infamia, libellus, liber, occentatio, probrosus, etc.), cf. HaffTer (1971) 100-110; Gil (1985) 112-122.

${ }^{104}$ Gil (1985)112, 118 e 137-138 (reforço da lex Cornelia; para a legislação citada, ver Rotondi (1966), Pereira (2008) sobre parrhesia e censura na antiguidade..

${ }^{105}$ Ver Gil (1985) 109 e 115-116; Cit roni (2006) 234.

106 Tac. Ann. 4. 34; Suet. A. 55-56. Cf. Suerbaum (1971) 78-80; Gil (1985) 133-134 (tratarse-ia de aparência externa a encobrir a política augustana de repressão literária). 
novidade não era a existência de legislação nova contra quem atacasse um alto magistrado, mas o facto temível de «haber acaparado el príncipe en su persona toda la maiestas del estado», mesmo quando não intervinha pessoalmente na repressão para se proteger politicamente ${ }^{107}$.

Deste modo, os testemunhos existentes parecem claramente indicar que o delito de opinião expressa em forma escrita não era passível de originar acusação, julgamento e condenação a não ser quando implicasse ofensa dirigida a alta personalidade e, tendo em conta os procedimentos legais, designando-a pelo nome, para fazer prova inequívoca em caso de citação em tribunal. Daí se compreender que Ovídio, quando insiste em atribuir a relegação a um carmen, não deixa de o mencionar para provar a falta de fundamento da acusação, como se, em pura táctica, antes procurasse esconder o motivo real ${ }^{108}$.

É evidente que os poderosos, como acontecera em Atenas, encontram forma de reinterpretar a lei ou tipificar a acusação de acordo com o seu propósito de penalizar os oponentes políticos. Parece ser essa a razão pela qual frequentemente a acusação é dupla, misturando, por exemplo, crime de adultério ou práticas mágicas com maiestas ou perduellio ${ }^{109}$. Logicamente, também os acusados procuravam distinguir entre ditos e actos, subtilizar conceitos jurídicos, enfatizar precedentes, de modo a conseguir a ilibação ou, pelo menos, a condenação por um crime de moldura penal menos gravosa.

Estas razões explicam a narrativa de Tácito sobre o processo de Clutório Prisco: quando foi acusado de ter preparado um elogio fúnebre para o caso de o enfermo Druso morrer, encontrou um único oponente à condenação à morte proposta no senado, Mânio Lépido, que argumentou serem as palavras coisa diferente de atentados ${ }^{110}$. Certamente por realismo, mas também sem êxito, Lépido dispôs-se a votar a pena de exílio como se efectivamente tivesse havido crime de maiestas. A reacção de Tibério foi de censura contra os senadores, por entender que simples palavras não deviam merecer penas tão severas ${ }^{111}$.

Também Cremúcio Cordo (Tac. Ann. 4. 35. 3-4), para cercear qualquer perseguição contra intelectuais, e em especial historiadores e poetas, argumentou que seria improcedente qualquer condenação: se o maledicente era de má qualidade, não se justificava o castigo, pois não teria eco ou eficácia; se era de boa qualidade, o castigo era ineficaz, pois o nome do eventual réu, pela sua qualidade artística, seria eternamente recordado; e apagar a memória

${ }^{107}$ GiL (1985) 129 e 138.

${ }^{108}$ Ov. Tr. 2. 2-4 (ingenio perii qui miser ipse meo? / Cur modo damnatas repeto, mea crimina, Musas?) e 207 (duo crimina, carmen et error); que se trata da Ars, é reiterado em Tr. 2. 7-8, 240, 345-346.

109 Cf. Suerbaum (1971) 98-99 (Appendix): Gil (1985) 118 ss. sobre os conceitos de maiestas e perduellio, e 130 sobre a elasticidade do conceito de magia.

${ }^{110}$ Tac. Ann. 3.50. 2: dicta a maleficiis differunt.

${ }^{111}$ Tac. Ann.3. 51. 2: modicas principis iniurias acriter ulciscentium, deprecaretur tam praecipitis uerborum poenas. É o mesmo raciocínio de Cremúcio Cordo quando elogia a liberdade de falar em Atenas, onde a um dito se responde com outro dito (Tac. Ann. 4. 35. 1: aut si quis aduertit, dictis dicta ultus est). 
de um talento era coisa que nem reis estrangeiros haviam tentado fazer ${ }^{112}$. Parece ser também esse o raciocínio subjacente em Ovídio quando, para além de silenciar o error, quanto a mim a causa do degredo, e insistir num delito com pouca ou nenhuma substância, intenta reversão da pena ou, pelo menos, a sua mitigação ${ }^{113}$.

Teríamos que admitir, em consonância, que condenações de intelectuais como Cássio Severo ${ }^{114}$, Ovídio ou Cremúcio Cordo, mais do que censura literária, seriam motivados por participação em ofensas explícitas à figura dos governantes ou da familia Caesaris, com agravamento no caso de serem dirigidas contra Augusto divinizado, ou em conhecimento ou participação em círculos de oposição e conjura - o error que Ovídio silencia? - , tudo matérias que a lei sobre maiestas contemplava desde tempos republicanos.

De facto, a argumentação expendida arreda a hipótese de Ovídio ter sido condenado por motivos literários, se o motivo invocado fosse a sua temática amorosa. Se o motivo foi dissonância e até hostilização da política augustana, então, ironia das ironias, o degredo de Ovídio serviu fortemente essa mesma política: do seu exílio em Tomos, com Tristezas e Cartas do Ponto, o Sulmonense contribuiu fortemente para o projecto Romano de colonização, contra as tentativas locais de enfermar a estabilidade do regime imperial, pese embora o facto de poder ter sido vítima de acção directa do imperador, o que prenunciava um regime mais duro e personalizado ${ }^{115}$.

\section{Do optimismo ao pessimismo}

Da transição da República para o Principado, com a Pax Augusta, o fecho do Templo de Jano e a celebração do regresso da idade do ouro nos Jogos Seculares, a que Horácio forneceu a força do seu talento e que Virgílio anunciava na Bucólica IV, vai nascer um optimismo que se espelha na crença de que a produção da época augustana atingira o esplendor máximo ${ }^{116}$.

Penso que esse tema de uma sociedade primeva se concretizou na literatura em expressões tão diversas como os motivos da idade do ouro, o tema da pax, o elogio da vida campesina e correspondente autarcia, e em manifestações tão diferentes como o De Senectute de Cícero, o quadro idílico das Bucólicas e o tratado técnico As Geórgicas, em vários cenários campesinos de Horácio ${ }^{117}$, e mesmo em elegíacos como Propércio (2. 19: no campo não há

112 Tac. Ann. 4. 35. 3-7: no fundo, a condenação funciona como um ingenii iudicium, para usarmos a expressão de Plin. Nat. praef. 6 e 7.108.

${ }^{113}$ Ov. Tr. 2. 118: grande tamen toto nomen ab orbe fero.

${ }^{114}$ Cássio Severo RE 89, foi condenado ao exílio e seus livros queimados (Tac. Ann.1. 72; sobre a sua personalidade, cf. Tac. Dial. 19.1 e 26. 4; Sen. Con. 3 praef. 5, 10 praef. 8; Suet. A. 56. 6). O mesmo destino terão os livros de Cremúcio Cordo (Tac. Ann. 4. 35. 5: Libros per aedilis cremandos censuere patres; set mansuerunt, occultati et editi; cf. Suet. Tib. 61. 10). Sobre queima de livros, ver Suerbaum (1971) 93 e n . 84.

${ }^{115} \operatorname{Ver}$ Gil (1985) 140-141 (represália pessoal de Augusto fosse qual fosse crime); Habinek (1998) 13-14 e 151-169.

${ }^{116}$ Sobre os temas da idade do ouro e conexos, ver Galinsky (1996) 90-121.

${ }^{117}$ Hor. S.1. 6, esp. v. 100 ss., 1. 8, com oposição Tíbur/Roma, 2. 6, Ep.1. 7 sobre a quinta da 
corruptores), Tibulo (1. 1, 10, 2. 1, 3 e 5) ou o próprio Ovídio. Deste, recordo Amores, 3. 13, uma viagem com a esposa para ver uma festa campesina em honra de Juno, a divindade do casamento. O reflexo da dualidade cidade/campo e o registo de uma imagem de supremacia poderão encontrar-se nos elogios da Itália e de Roma (Romael Italiae laudes), que se distribuem por autores tão diversos como Cícero, Varrão, Virgílio, Tito Lívio, Manílio, Séneca, Plínio o Antigo ${ }^{118}$.

Um acto significativo dessa nova época de paz, consentida pela ausência de guerra, consistiu no já referido fecho simbólico do Templo de Jano, em 29 a.C. Com esse gesto gravado em Res Gestae ${ }^{119}$, Augusto criou uma situação irreversível que foi confirmada com a adopção de uma política de contenção imperialista, em favor da paz, do comércio e da diplomacia ${ }^{120}$. Ora, a problemática do imperialismo, e consequentemente da guerra, era uma questão na ordem do dia, presente em Lucrécio, analisada no livro III do Tratado da República através dos discursos duplos de Carnéades, que num dia pôs a justiça na base do império, e no seguinte demonstrou exactamente o contrário, subjacente ao discurso de Mémio em Salústio (Jug. 31). Se Augusto propagandeava uma época de paz, como poderia ele ficar ofendido com a recusa da musa épica?

Este cúmulo de felicidade e bem-estar respondia à restauração postulada por Cícero e implicava, por isso, a crença no regresso de uma idade do ouro que assumia também a faceta de regresso ao passado enquanto modelo ético e político, o qual, por influência retórica e de acordo com tradição que já vinha dos Gregos ${ }^{121}$, simultaneamente funcionava como crítica contra os desmandos do presente. Não admira, por isso, que o elogio de uma fase primitiva da natureza, de uma vida de tipo theriodes, frugal, ascética, agradasse a pensadores e intelectuais tão diferentes como Lucrécio ${ }^{122}$,

Sabina, Epod. 2, apesar do final paródico.

${ }^{118}$ Ver Oliveira (2005a).

${ }^{119}$ Res Gestae 13; em Ovídio o tema da Paz, por vezes em ligação ao fechamento das portas do Templo de Jano, ocorre em Fast. 1. 277-282, 701-704, 709-724 (Ara Pacis), 3. 881-882 (com Concordia e Salus); cf. Suet. A. 22.

${ }^{120}$ Cf. Res Gestae 27.2 (política de diplomacia na região da Arménia), 31-33 (diplomacia e política de protectorados; cf. Suet. A. 60). Sobre abusos dos Romanos nas províncias, cf. Sal. Hist. 6, Carta de Mitridates; discurso de Carnéades em favor da injustiça em Cic. Rep. 3. 20-28; Tac. Ag. 19 e 30). Augusto teria deixado, em Res Gestae e outros documentos, orientações para o sucessor, incluindo a suspensão da política expansionista: cf. Tac. Ag. 13 e Ann.1.11; Vell. 2. 124 . 3; Strab. 6. 4. 2 e 7.1.4; D. C. 56. 33. 3. Ver Ramage (1987) 115.

${ }^{121}$ Veja-se o elogio aristofânico dos heróis de Maratona, época idealizada em passos como Ach. 181, 697-698 e Nu. 986; cf. Salústio, e.g. 5. 9 e 6-13; Cícero, para além do elogio geral do mos maiorum "costumes dos antepassados» (Rep. 3-41 e 5.1-2), parece colocar também os costumes na origem do direito (Rep.1.2 e 2.64; em Leg.1. 43 ss., 2.11 ss., enfatiza a necessidade de a natureza confirmar o direito, o que, segundo 2. 23, teria acontecido tanto na constituição como no edifício jurídico romano tradicional).

${ }^{122}$ Lucr. 5.783 ss., 925 ss., onde, todavia, a idealização retórico-filosófica do passado não impede a crença no progresso, tendo em conta a juventude da terra (5. 330-332: uerum, ut opinor, habet nouitatem summa recensque / naturast mundi, neque pridem exordia cepit. / Quare etiam quaedam nunc artes expoliuntur, / nunc etiam augescunt, cf. 5. 780; a ideia de progresso acentua-se na fase civilizada, onde, como remédio para os erros, a uera uoluptas (5. 1433) não impede o 
Tibulo $^{123}$, Propércio, em particular 4.11 sobre as virtudes tradicionais romanas, e Ovídio ${ }^{124}$, se traduzisse em manifestações tão diferentes como o interesse pela arqueologia de Roma, exemplificado no livro II do Tratado da República, nas Antiquitates de Varrão, nas lendas das origens de Roma em Tito Lívio, e em trechos tão diversos como o Canto VIII da Eneida (visita a Evandro), elegias várias do livro IV de Propércio, nas Metamorfoses e nos Fastos de Ovídio, e tornado visível na reconstituição, no cimo do Palatino, da Casa Romuli.

Mas, ao dar resposta a essa crise de valores tão bem ilustrada por Lucrécio ou por Catulo e mesmo entrevista em Ovídio ${ }^{125}$, o optimismo augustano, que vai propagandear ter o regime de Augusto trazido a perfeição em todos os domínios, supõe a cura dos males existentes e com isso, paradoxalmente, funda os alicerces de um pessimismo que levará a correntes estéticas adversas. Trata-se de algo semelhante ao afirmado por Cícero a propósito da decadência expectável da oratória a partir do cesarismo, depois de a mesma ter atingido o seu zénite ${ }^{126}$. Tal optimismo tem, no campo literário, afloramentos muito ricos, mesmo antagónicos, como se adivinha: assim, apesar do ideal de regresso ao passado, a época augustana vai substituir o pater Ennius por um astro literário coevo, Virgílio ${ }^{127}$, e nisso dá seguimento às preferências estéticas neotéricas contra as quais Cícero se rebelara (Tusc. 3. 45) 128; vai fomentar a emulação dos literatos no sentido de reivindicarem a criação de novas espécies literárias, como no caso de Horácio quando se proclama o Arquíloco latino esquecendo Catulo, ou no de Ovídio a propósito das Heroides, mesmo quando a novidade não é absoluta $^{129}$. Ora, a crença no progresso alcançado irá esgotar a veia clássica e gerar um pessimismo que se virá a traduzir em anseios artísticos anti-clássicos, como no caso de Lucano, que arreda toda a maquinaria mitológica tão cara aos autores tardo-republicanos e augustanos, de Cícero a Virgílio e a Ovídio.

Será que esta reacção, consequência fatal da própria crença implícita no devir cíclico, já se adivinhava quando o regime augustano terá inflectido a sua

progresso contínuo (5.1453), graças à descoberta da verdadeira moral por Epicuro, em Atenas (6. 1. 43: solacia dulcia uitae, ueridicis dictis, recto cursu, passo que remete para 3. 1-30: commoda uitae, rerum inuentor, aurea dicta, diuina uoluptas).

${ }^{123}$ Tib. 1. 3. 35-50, 1.10.1-12, 2. 1. 37-78, 2. 3, esp. v. 35-49 e 68-80; cf. Galinsky (1996) 270 ss. (Tibulo não rejeita os valores augustanos).

124 Ov. Ars 2. 467-492, 621-624.

125 Cf. Citroni (2006) 363-363 para Catulo e 394-395 para Lucrécio; Ov. Med. 11-25 contrapõe a beleza rústica das Sabinas aos excessos de toilette das mulheres e até dos homens da sua época.

${ }^{126}$ Cic. Brut., 1-6; Citroni (2006) 288.

127 Neste aspecto, Cecílio Epirota é um inovador, ao abrigar autores contemporâneos no currículo pedagógico; cf. Hor. Ep.2.1, uma espécie de querela entre antigos e modernos, НавіNeк (1998) 106-107.

${ }^{128}$ Também Tac. Ann. 3. 55, elogia Vespasiano e mostra que a sua época forneceu exemplos que não ficam atrás dos do passado (nec omnia apud priores meliora); Plínio, no geral elogiando o passado, ocasionalmente também o censura (Nat. 36. 4), acabando por fazer uma síntese na figura de Vespasiano (Nat.2.18: proceres Romani ... nunc Vespasianus; cf. Oliveira (1992) 129 n. 231, 288-289); cf. Lucr. 3. 1024 ss.: desprezo pelas grandes figuras da antiguidade.

${ }_{129}$ Para Horácio, cf. Ep. 1. 19, Citroni (2006) 518; para Ovídio, ver Ars, 3. 341-346; cf. Prop. 4. 3: carta de Aretusa a seu marido. 
Francisco de Oliveira

política de mecenatismo prazenteiro para uma veia mais autoritária, após o afastamento de Mecenas por 23 a.C. e a sua morte em 8 a.C.? Pelo menos, não se pode negar que tanto as Geórgicas como a Eneida têm suscitado leituras que vão nesse sentido ${ }^{130}$.

${ }^{130}$ Tac. Ann. 3.30, a propósito de Mecenas: ...aetate prouecta speciem magis in amicitia principis quam uim tenuit. 